\title{
Accumulate Motherland in Russian and Bulgarian Linguocultures
}

\author{
Avramova Valentina Nikolova ${ }^{1}$ \\ Professor, University of Shumen Bishop Constantine Preslavski, \\ Shumen, Bulgaria. \\ (date of receiving: September, 2017; date of acceptance: January, 2018)
}

\begin{abstract}
The article deals with the accumulation of the Motherland in Russian and Bulgarian linguocultures. The essence of the term we have proposed is explained. Attention is drawn to the similarities and differences in the use of the units under consideration, which serve to solve the national phenomenon, expand the concept of the linguistic picture of the world, and understand the specific features of different cultures. In the paper, the values of the accumulation in explanatory, synonymous, etymological dictionaries, prosaic and poetic texts, folklore (proverbs and sayings) are stated, as well as statements and thoughts of personalities with national authority. Attention is also drawn to the extralinguistic factors that led to the emergence and use of this phenomenon. Descriptive, taxonomic, comparative-historical and comparative methods are used in the work as general methods of linguistic research. As, an auxiliary component analysis was used to identify all the semantic parts of the linguistic unit that represents the accumulation. The results of the study showed a common and different in the accumulation in question in two linguocultures - Russian and Bulgarian.
\end{abstract}

Keywords: Accumulation, Homeland, Motherland, Fatherland, Tatkovina, Native Country.

1. E-mail: valentav@abv.bg 


\title{
Аккумулема родина в русской и болгарской лингвокультурах
}

\section{Аврамова Валентина Николова ${ }^{1}$}

Профессор Шуменского университета им. Епископа Константина

Преславского,

Шумен, Болгария.

(дата получения: сентябрь 2017 г.; дата принятия: январь 2018 г.)

\begin{abstract}
Аннотация
В статье рассматривается аккумулема Родина в русской и болгарской лингвокультурах. Объясняется суть предложенного нами термина аккумулема. Внимание обращается на сходства и различия в употреблении рассматриваемых единиц, служащих для разгадки феномена национального характера, расширения представлений о языковой картине мира, понимания специфики различных культур. В работе изложены значения рассматриваемой аккумулемы в толковых, синонимических, этимологических словарях, в прозаических и поэтических текстах, в фольклоре (пословицах и поговорках), приведены также высказывания и мысли личностей с национальным авторитетом. Внимание обращается также на экстралингвистические факторы, обусловившие появление и употребление данного феномена. В работе использованы описательный, таксономический, сравнительно-исторический и сопоставительный методы, как общие методы лингвистических исследований. В качестве вспомогательного был использован компонентный анализ для выявления всех семантических долей рассматриваемой языковой единицы, представляющей аккумулему. Результаты исследования показали общее и различное в рассматриваемой аккумулеме в двух лингвокультурах - русской и болгарской.
\end{abstract}

Ключевые слова: Аккумулема, Родина, Отчизна, Отечество, Татковина, Родна Страна.

1. E-mail: valentav@abv.bg 


\section{Введение}

Аккумулема Родина привлекает внимание исследователей, так как она теснейшим образом связана как с этническим самосознанием, так и с жизнью населения каждого государства. Для названия данного понятия в современной лингвистике используются различные термины, каждый из которых имеет свои параметры, например, концепт, лингвокультурема, константа, ключевое слово, логоэпистема, социокультурный стереотип и др.

Аккумулема Родина является одним из самых универсальных ключевых понятий, имеющих место в работах исследователей, это понятие присутствует в любой этнической общности. В исследованиях особо подчеркивается тот факт, что „общечеловеческая ценность Родина является реляционным понятием: в его структуре обязательно должно быть наличие параметра отношения, это всегда „персональное”, „свое” („мое”) личностное место (места), архетипически противопоставленное „чужому” месту, чужбине” (Телия 1997. 78). Аккумулема Родина является одной из важных ментальных констант этнической общности, составляющих, в частности, русскую и болгарскую картины мира.

Согласно Ю.С. Степанову становление концепта «Родина» в русской ментальности - это «некая линия, которая раздваивается, и, с одной стороны, этот концепт смыкается с представлениями об особой русской религиозности, а с другой, с особым русским отношением к своей стране и земле как к матери» (Степанов 2007. 20).

Предложенный нами термин аккумулема „содержит в кодированном виде проявления ментальности. В содержание аккумулемы включаются парадигматические, синтагматические и словообразовательные связи слова, вся парадигматическая информация языкового знака, связанная с его экспрессивной и иллокутивной функцией. Синтагматическую значимость эксплицируют коннотации определяемого слова, которые носят культурно 
обусловленный характер, так как они отражают традиции словоупотребления в данном языке. ... Значения аккумулемы вербализуются в значениях слов, фразеологических единиц, предложений, афоризмов, пословиц, поговорок, ключевых слов, логоэпистем, прецедентных текстов и имен, названий литературных произведений и отрывков из них, различных текстов, являющихся частью духовной культуры лингвокультурной общности.

Аккумулема представляет собой максимально абстрактную, но конкретно кодированную в языковом сознании единицу ментального уровня, исторически детерминированную, структурированную общечеловеческими и наџиональноспецифическими представлениями, вербализованными в словах или словосочетаниях, сосредоточивших накопленную человечеством $и$ лингвокультурной общностью культурную информацию” (Аврамова 2007. 114-116).

\section{Основная часть}

Репрезентации признаков аккумулемы Родина, объективируются лексическими единицами слов-стимулов рус. - родина, отечество, отчизна, государство, мать-земля; болг. - родина, отечество, татковина, държава.

В Толковом словаре живого великорусского языка В. Даля и в Словаре болгарского языка Н. Герова, изданных в конце XIX в., лексема Родина отсутствует. В данных словарях отмечены лексемы рус. отечество, отчизна; болг. отечество.

В Толковом словаре живого великорусского языка В. Даля отечество толкуется как „родная земля, отчизна, где кто родился, вырос; корень, земля народа, к коему кто, по рожденью, языку и вере, принадлежит; государство в отношении к подданным своим; родина в обширном смысле; Отец мой выходец, а мое отечество Русь, руское государство." Родина здесь употребляется в значении „место, край, где кто-л. родился”. Отчизна 
определяется как „отечество, родина. Рыбам море, птищам воздух, а человеку отчизна вселенный круг. Отчизнушка, отчизненка ты моя!” (Даль 1979. Т.2. 724).

В „Речник на българския език” Н. Герова присутствует только слово Отечество, определенное как бащиния, татковина (Геров 1977. 407).

Среди славянских языков только в русском и болгарском языках слово родина имеет значение „отечество, место рождения”, в остальных языках отмечены значения „семья” и „обилие плодов” (Фасмер 1971. Т.4. 491).

В словарных статьях аккумулема Родина, выраженная словами и словосочетаниями, включает ядерные смыслы, репрезентирующие архетипические и энциклопедические представления об этом понятии. Представим значения слова родина по данным словарей в русском и болгарском языках.

В русском языке: 1. Страна, в которой человек родился и гражданином которой является; отечество, государство: Любовь к родине. Защчита родины. // Место рождения кого-л.; 2. Место рождения, происхождения чего-л., возникновения чего-л. (СРЯ 1983. 723): Москва - его родина; Индия - родина шахмат (ТСРЯ). В русском языке существуют также понятия малая родина земля, край отцов, где живут родные и близкие; большая родина-государство, в котором человек родился; вторая родина - место, давшее кому-нибудь приют, ставшее родным (ТСРЯ); Родина-мать.

В русском языке имеется также лексема кольбель, обозначающая место, страну, где что-л. появилось впервые, ср. Академия сделалась кольюелью новой русской науки. С. Вавилов.

В болгарском языке отмечены следующие значения рассматриваемой аккумулемы: 1. Страната, в която някой е роден, откъдето произлизат предците му или където е отрасъл; отечество, татковина // Територия, населявана от даден народ; отечество; 2. Място, територия, откъдето 
произлиза и обикновено откъдето се е разселила някаква общност от хора (народ, племе и пр.); прародина, праотечество; 3. Прен. Място откъдето произлиза или където е възникнало нещо. България е родината на славянската писменост. 4. Остар. Родно място. Близо до Охрида е Струга, родина на двамата братя Миладинови (РБЕ 2015. 1381-1382). В этом последнем примере лексема родина имеет значение „родное место, роселок”, существующее в современном русском языке и употребляющееся в настоящее время, в то время, как в болгарском языке это значение устарело.

Слово родина происходит из др.болг. слова *радъ (род), имеющего значение „группа родственных семей с общим хозяйством, образующих основную общественную единицу в первобытнообщинном строе”, в народном сознании слово присутствует со значением „народ, племя; ответвление, поколение; лица, близкие по крови и сватовству, семья, фамилия” (БЕР 2002. 294). Часть вышеперечисленных значений связана со значением родина. Второе значение в данном словаре - это „место, где родился человек”, а третье - „место рождения человека”; употребительны также словосочетания роден дом, родно селище, роден край, родна страна. Но в БЕР слово родина не присутствует. Нет его и в Словаре болгарского языка Н. Герова, впервые опубликованного в 1885-1904 г. В этом словаре для названия рассматриваемого понятия помещено слово отечество „бащиния, татковина; отечество, отчизна”. Слово родина вошло в употребление лишь в XVIII-XIX вв. (Касабова 2002. 36). Во время Первого болгарского царства (681-1018) и Второго болгарского царства (1185-1396) государства имели названия болгарское иарство, болгарская страна, болгарская земля и болгарское государство. После освобождения от османского владычества (1878) и восстановления самостоятельного болгарского национального государства понятие родина приобрело значение национального государства. Тем не менее, и в эпоху Болгарското Возрождения (XIX в.) и после Освобождения (1878) 
имена отечество и татковина были весьма употребительны в болгарской литературе, ср. Отечество мило любя, неговият завет пазя (Хр. Ботев); Обичам те, мое мило отечество! Обичам твоите балкани, гори, сипеи, скали (Л. Каравелов); Хубава ни, татковино, име сладко, земя рай! (Ив. Вазов).

Рассматриваемая аккумулема имеет определенный круг синонимов в обоих языках. В русском языке - это отчизна, отечество (слова торжественной, возвышенной речи); кольбель (место, где человек родился, провел свое детство и юные годы; употребляется в приподнятой, поэтической речи), родная сторона, отчий край, родная земля, земля отцов, родная сторонка, родные палестины устар. (Гололобов, Меняйлова 2017. 1-4). В болгарском языке употребляются лексемы отечество (то же, что и родина, но с эмоциональной окраской); татковина (то же, что и отечество, но с еше более подчеркнутой эмоциональной окраской); люлка (колыбель перен.знач.); бащуиния устар. нар. (родная страна, край, место, где человек родился, вырос, с которой его связывают сильные чувства принадлежности по роду и языку), земя на дедите высок., роден дом, роден край. В современном болгарском языке старое значение слова „бащиния” заменилось полностью подчеркнуто негативным значением, обозначающим что-либо не принадлежащим человеку, которым он неправомерно распоряжается (имуществом, служебным положением и т.п.)

Отношение этнического человека к родине находит выражение и в национальных пословицах и поговорках. Для русского человека Родина всегда была чем-то очень важным, близким, родным, без чего невозможно жить. Подтверждением этому факту служат множество поговорок и пословиц, например: Человек без Родины - соловей без песни; В гостях хорошо, а дома лучше; Где кто родился, там и пригодился. В России, как отмечает С.Г. ТерМинасова, любовь к Родине является неотъемлемой чертой национального характера, которая проявляется у русских открыто и эмоционально, чему 
свидетельствует язык (Тер-Минасова 2000. 176). Ссылаясь на пословичный фонд русского языка, напрашивается вывод о высочайшей степени патриотизма русского народа. Русский человек чувствует себя чужим на „другой” стороне, „болеет” за свою Родину, поддерживает ее и любит, ср. Нет ничего на свете краше, чем родина наша; За морем веселье, да чужое, а у нас и горе, да свое; Любовь к родине сильнее смерти; Родных нет, а по родимой сторонке сердие ноет; С родной земли - умри, не сходи; Своя земля и в горсти мила.

Русский язык неопровержимо свидетельствует о такой черте русского национального характера, как открытый патриотизм, словесно выраженная любовь к родине. Особенно ярко эта черта проявляется при сопоставлении русского языка с английским. Действительно, русский язык изобилует эмоционально окрашенными словами, обозначающими место рождения человека, край, страну, где человек родился: родина, моя родина, родная страна (сторона/сторонка), отечество, отчизна. Эти слова и сочетания с ними имеют положительные коннотации, делают речь более эмоциональной. Часть аккумулемы Родина выражается в понятии „тоска по родине”, устойчивое выражение, зарегистрированное словарем под редакцией Д.Н. Ушакова.

Ю.С. Степанов рассматривает становление аккумулемы Родная земля как „некую линию, которая раздваивается, и с одной стороны, этот концепт смыкается с представлениями об особой русской религиозности, а с другой, с особым русским отношением к своей стране и земле как к матери или как к жене" (Степанов 2007. 20).

В русской культуре образ родины матери восходит к архетипу праматери как началу и источнику всего живого. Жизненный путь человека заканчивается возвращением в лоно матери сырой земли. В русской речи известны и такие выражения как Родина-мать, мать-сыра земля, земля- 
матушка, подтверждающие мысль о том, что в русском подсознании понятие Родина имеет сакральное значение и ассоциируется с матерью, ср. Береги землю родимую, как мать любимую; Родимая сторона - мать, чужая мачеха.

Родина - это 'место, где человек родился', ср. Здесь моя родина. В современном русском языковом сознании этот признак соответствует понятию малая родина, ср. А родина у меня особенная: село знаменитое, у него потрясающая история (Аграрный журнал, 15.02.2002); Дедушка давно мечтал посетить места, где родился, где лежат в могиле его предки, одним словом - родину («Звезда», 2003, № 6); Тоска меня берет по родине (фильм „Калина красная”).

В болгарской культуре в качестве синонимов аккумулемы Родина используются лексемы отечество, отечина устар., отчина устар. с общим значением „род человека, поколения одного рода, место, где человек родился”. Понятие татковина имеет стилистическую окраску „высокое” и используется в эмоциональном и возвышенном контексте, в художественных произведениях (преимущественно XIX в.), в публицистике, в официальной речи, где слова участвуют в создании торжественной тональности текстов ср. Хубава си, Татковино, име сладко, земя рай!

Как ни странно, но в болгарском фольклоре отсутствуют пословицы на тему о родине, об отечестве. Данному факту есть объяснение и оно кроется в фактах истории болгарского народа. Болгарская общественная жизнь, развитие гражданского общества было прервано порабощением болгарских земель завоевателями Османской империи. И это длилось целых пять веков (1396$1878)$ - период, когда у болгар не было национального государства, хотя названия Болгария, болгарская земля сохранились за болгарской территорией за все время османского ига. Болгары не смогли воспринять взаимоотношения, чужие их ментальности, поэтому жизнь болгар сосредоточилась в семье, в 
родственных отношениях. Издевательства и зверства поработителя заставили населения замкнуться в своей семье, которая была многочисленной. Семья, род, близкие люди заменили болгарину родину. Ср. отголоски этого чувства в устойчивых сочетаниях тех времен, употребленных писателями эпохи Болгарского Возрождения: Стари обичаи на презирай! Бащчино огнище не забравяй! Г.С. Раковски (Старинных обычаев не презирай! Отчий очаг не забывай!); Няма по-топла стряха от бащчината и по-успокоително небе от родното. П.К. Яворов (Нет теплее родной крыши и неба спокойнее, чем родное небо). В эпоху Болгарского Возрождения (XVIII-ХIХвв.) появилось понятие Отечество, употребляемое вначале борцами за свободу болгар. Это был трудный и тяжелый путь, которому сопутствовало постепенное осознание заявить миру о том, что у болгар есть Отечество, путь, осеянный многочисленными жертвами. Об этом осознанном праве говорят первые идеологи национально-освободительной борьбы, сp. Любовта към Отечеството превъзхожда всички световни добрини и тя е найутешителната мисъл за човека на този свят. Г.С. Раковски (Любовь к Отечеству превосходит все добро, существующее в мире; она является самой утешительной мыслью в этом мире); Аз съм се посветил на отечеството си жертва за освобождението му, а не да бъда кой знае какъв. Васил Левски (Я посвятил свою жизнь отечеству и буду жертвовать собой для его освобождения, я не хочу быть никем); Човек живее за себе си, но в същзото време той живее и за своето Отечество, за своите родители и за своите децุa. Л. Каравелов (Человек живет для себя, но также и для своего Отечества, ради своих родителей и детей); Мила ми Венето, след Отечеството наймного обичам теб. Христо Ботев (Моя милая Венета, после Отечества я люблю больше всего тебя).

Другие чувства к Отечеству наполняют сердце болгарина в уже освобожденной родине в результате Русско-турецкой войны 1877-1878 гг. Эти 
чувства точно переданы в строках болгарских поэтов. Вот некоторые примеры: Отечество любезно, как хубаво си ти! / Как чудно се синее небето ти безкрайно! / Как твоите картини меняват се омайно! Иван Вазов (Мое милое Отечество, как ты красиво! Бескрайнее небо синеет надо мной! Твои завораживающие пейзажи проплывают предо мной!); Българио, за тебе те умряха, една бе ти достойна зарад тях, и те за теб достойни, майко бяха. И твойто име само кат мълвяха, умираха без страх. Иван Вазов (Болгария, во имя твоей свободы они умерли, ты для них была достойной так же, как и они для тебя. Они без страха умирали с твоим именем на устах); Опознай Родината, за да я обикнеш! Алеко Константинов (Узнай свою Родину для того, чтобы полюбить еe!).

Любопытные рассуждения предлагает исследователь Я. Янев, говоря о сути понятий Родина и Отечество в болгарской ментальности. Он пишет: „К Родине у нас не должно быть одно сентиментальное отношение. Родина требует безусловной привязанности, которую ни за что на свете невозможно опорочить. Она является символом абсолютной отдачи, для которой никакая жертва не является слишком большой. Родина выше всего. Это мать, которая рождает историю, дает жизнь культуре, определяет смысл любого личного и общественного существования. Без родины мир как будто без субстанции, человек без органической основы, а жизнь - это поток, разливающийся в проклятьи и злобе. Именно в этом и состоит и личная, и я бы сказал, и метафизическая обреченность, которая обусловливает чувство родины.

Если эта обреченность имеет политический характер, родина становится отечеством. Родина имеет мифологическую сущность, отечество политическую. Родина является поэмой, отечество - эпос. Родина - это женственное начало, праматеринский Святой дух бытия. Отечество - это мужественное и воинствующее начало. Основы Родины лежат в философии страстного желания, основы отечества - в философии подвига. Родину мы 
воспеваем, за отечество боремся. Родина - это завещание, последнее искупительное лоно" (Янев 1934. 266).

Вышеприведенные строки вносят ясноту в различие смыслового наполнения аккумулемы Родина в русской и болгарской ментальности. В рассматриваемых языках обнаруживаются общие значения рассматриваемой аккумулемы, но также и специфические, обусловленные устоявшимися в национальном языковом сознании значениями.

Этот пафос еще в большей степени выражен в словах Отчизна, Отечество. Они имеют общий старославянский корень, в котором заключается значение «родовые права», «наследие, переходящее от отца к сыну».

Для русского национального сознания характерна идея Руси-матушки, которая берет начало в фольклорном образе Матери-сырой земли, русском варианте Великой Богини-матери. Понятие Русь-матушка характеризуется оттенком задушевной теплоты в то время, как Родина-мать - это высокое слово, призыв, величественность.

В петровскую эпоху для обозначения государства чаще используется термин Отечество, однако и образ России-Матери появляется в текстах, например, Феофана Прокоповича, а позднее В. Тредиаковского и М. Ломоносова. Выражение Родина-мать употреблялось в русском языке еще в XIX веке. В период Октябрьской революции и Гражданской войны образ Родины-матери используется сторонниками Белого движения. В идеологии большевизма образ России-матушки игнорировался или использовался как символ отсталости царской России. В период Великой Отечественной войны, в самом начале которой появился плакат И. Тоидзе Родина-мать зовет!, этот образ стал символом борьбы против немецких захватчиков.

Чувство привязанности и любви к Родной земле индивидуально. Обычно предполагается, что объект патриотических чувств всегда один - родина. Вместе с тем, у этого имени много образов: родина - это и страна, это и 
отчизна, и место, где родился и вырос человек, и где живут друзья и близкие ему люди. Кроме того, это еще и государство. В сознании многих людей эти понятия приравниваются. Хотя в настоящее время фраза „Люблю свою страну, но не люблю государство" стала очень актуальной и в России, и в Болгарии, но причины ее появления уже восходят к отдельной идеологии и современному состоянию государства. Причины кроются в разрушении привычного существования, которое разрушилось и обрушилось на людей и которое не принесло нового, покоя, устроенности, а ухудшило их жизнь. Надежды людей были обмануты, и это обстоятельство вызвало еще более сильное негодование людей и неприязнь к государству.

С образом Родины связано и чувство ностальгии, характеризующее представителей обеих рассматриваемых лингвокультурологических групп. Словарное значение данного слова определяется, как „1. тоска по родине, по родному дому; 2. по чему разг. тоска о прошлом, о пережитом, об утраченном. H. по родному селу" (БТС). Тоска по родине проявляется в том случае, когда этнический человек вынужден покинуть свою родину. Этот акт уже связан не с ментальностью индивида, а с историей страны. Русские сталкивались с этой проблемой после Октябрьской революции, когда многие россияне эмигрировали из своей родины. В первой половине XX века многие болгары ездили на заработки в чужие края для обеспечения своих семей. Этот акт имеет свое название - гурбет. Вынужденная разлука с родиной всегда порождает ностальгию. В эту эпоху и русские, и болгары одинаково страдали вынужденной разлукой с Родиной.

\section{Заключение}

Наблюдения над вербализацией аккумулемы родина и отношения к ней в русском и болгарском обыденном сознании показывают общие и различные маркеры в этом отношении. Анализ лексических значений синонимов 
аккумулемы родина в обоих языках позволяет сделать заключение о том, что они дифференцируются по своей семантической структуре и имеют специфические семантические доли в каждом языке. Устойчивые сочетания с лексемой родина связаны с идеей долга перед родиной и любви к ней. Функционирование аккумулемы в различных контекстах позволило выделить как универсальные, так и ее специфические признаки. В паремиологическом фонде каждого из рассматриваемых языков, а также в литературных текстах выкристаллизован образ родины - в русской ментальности в древнем архетипе матери-земли (Россия-мать), в болгарской ментальности - в образе мужского начала (Отечество, Татковина), являющиеся актуальными, каждая в своей культуре. Родину можно отнести, если не к ключевым словам каждой культуры, то к числу самых значимых аккумулем каждой национальной лингвокультуры.

\section{Литература}

1- Аврамова В. (2007), Лингвокультурология, Шумен, Унив. Изд-во «Епископ Константин Преславски».

2- Гололобов В.Г., Меняйлова Т.А. (2017), Слово „Родина” в русском языке и в жизни людей (лингвокультурологическое исследование). // Юный ученый, 2017, № 4, c. 1-4 URL:http://yun.moluch.ru/archive/13/1022/дата обращения: 10.02 .2018

3- Степанов Ю.С. (2007), Концеепты. Тонкая пленка цүивилизациий. Москва, Изд-во «Языки славянских культур».

4- Телия В.Н. (1997), Наименование Родина как часть социального концепта „Раtria” в русском языке. // Языковая категоризация: материаль круглого стола, посвященные юбилею Е.С. Кубряковой по тематике ее исследования, Москва.

5- Тер-Минасова С.Г. (2000), Язык и межкультурная коммуникация. Учебное пособие, Москва, Изд-во «Слово/Slovo».

6- Янев Я. (1934), Философия на Родината, ж. Златорог, София, 1934, № 6, с. 263-266.

7- Kassabova A. (2000), Migration und Familie. Familienforschung und Politik (Am Beispiel Bulgariens), Sofia, Изд-во «Variant». 


\section{Bibliography}

1- Avramova V. (2007), Lingvokul'turologija, Shumen, Univ. Izd-vo «Episkop Konstantin Preslavski».

2- Gololobov V.G., Menjajlova T.A. (2017), Slovo „Rodina” v russkom jazyke $i$ v zhizni ljudej (lingvokul'turologicheskoe issledovanie). // Junyj uchenyj, 2017, № 4, s. 1-4 URL:http://yun.moluch.ru/archive/13/1022/data obrashhenija: 10.02.2018.

3- Stepanov Ju.S. (2007), Koncepty. Tonkaja plenka civilizacij. Moskva, Izd-vo «Jazyki slavjanskih kul'tur».

4- Telija V.N. (1997), Naimenovanie Rodina kak chast' social'nogo koncepta „Patria” $v$ russkom jazyke. // Jazykovaja kategorizacija: materialy kruglogo stola, posvjashhennye jubileju E.S. Kubrjakovoj po tematike ee issledovanija, Moskva.

5- Ter-Minasova S.G. (2000), Jazyk i mezhkul'turnaja kommunikacija. Uchebnoe posobie, Moskva, Izd-vo «Slovo/Slovo».

6- Janev Ja. (1934), Filosofija na Rodinata, zh. Zlatorog, Sofija, 1934, № 6, s. 263 266.

7- Kassabova A. (2000), Migration und Familie. Familienforschung und Politik (Am Beispiel Bulgariens), Sofia, Izd-vo «Variant».

\section{HOW TO CITE THIS ARTICLE}

Avramova Valentina Nikolova (2018). Accumulate Motherland in Russian and Bulgarian Linguocultures, Issledovatel'skiy Zhurnal Russkogo Yazyka i Literatury,11(1): pp:11-25.

DOI: 10.29252 /iarll.11.11

URL: http://journaliarll.ir/article-1-127-en.html.

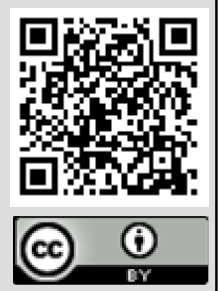




\title{
جكيدهاى فارسى
}

\section{مفهوم وطن در فرهنگ زبانى روسى و بلغارى}

\author{
واليتينا نيكولووا آورامووا' نيكاه

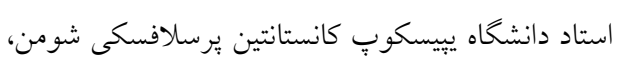 \\ شومن، بلغارستان.

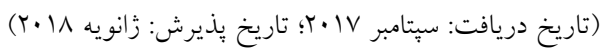

مقاله حاضر به بررسى مفهوم ميهن و وطن در فرهنخ زبانى روسى و بلغـارى مسى منسردازد.

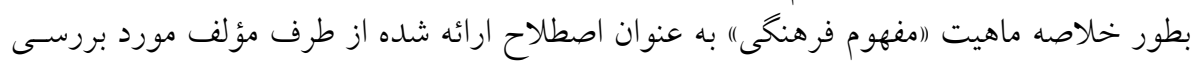

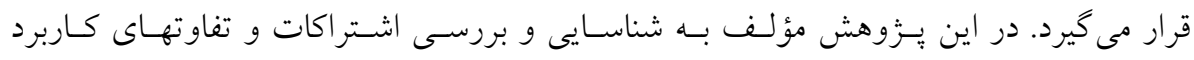

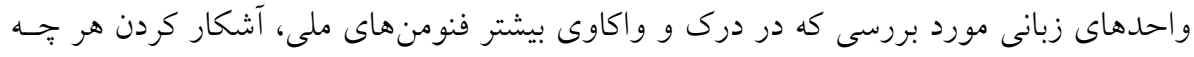

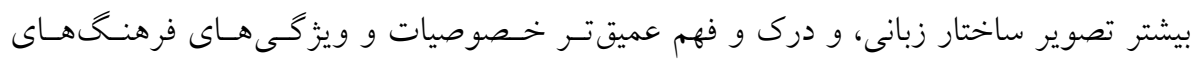

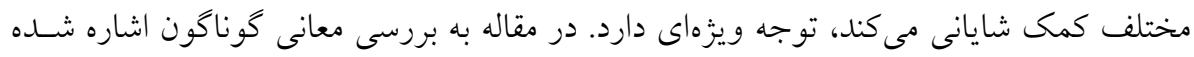

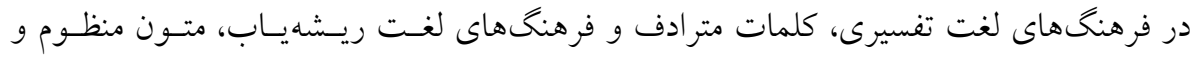

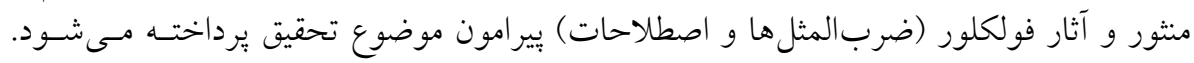

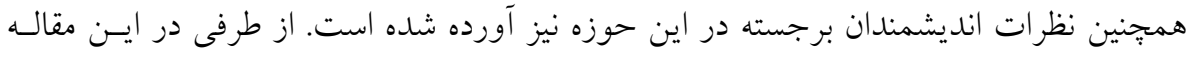

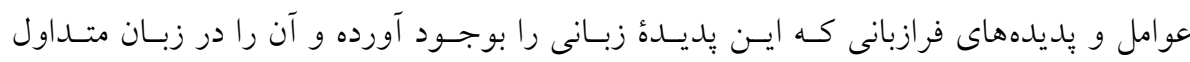

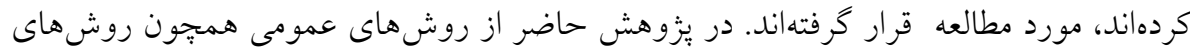

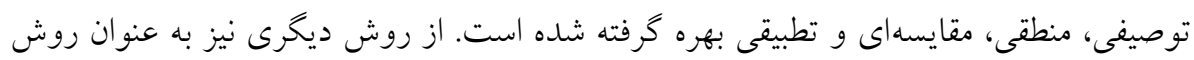

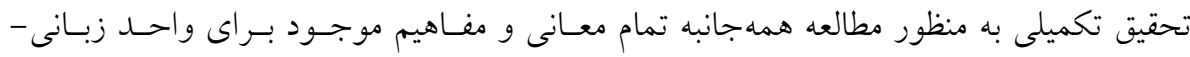

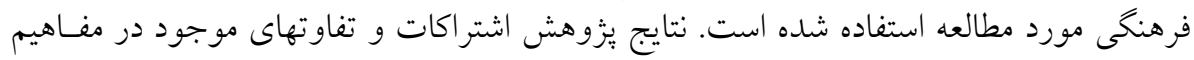

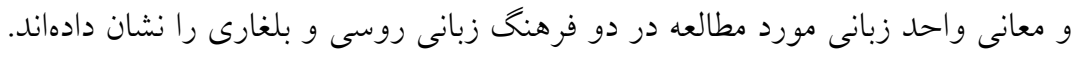
وازگان كليدى: مفهوم فرهنگى، وطن، ميهن، زادگاه، كشور زادكاه، سرزمين مادرى. 